\title{
The down-regulation of the CYP2C19 gene is associated with aggressive tumor potential and the poorer recurrence-free survival of hepatocellular carcinoma
}

\author{
Ryo Ashida $^{1}$, Yukiyasu Okamura ${ }^{1}$, Keiichi Ohshima ${ }^{2}$, Yuko Kakuda ${ }^{3}$, Katsuhiko \\ Uesaka $^{1}$, Teiichi Sugiura ${ }^{1}$, Takaaki Ito ${ }^{1}$, Yusuke Yamamoto, ${ }^{1}$ Takashi Sugino ${ }^{3}$, \\ Kenichi Urakami ${ }^{4}$, Masatoshi Kusuhara ${ }^{5}$ and Ken Yamaguchi' \\ ${ }^{1}$ Division of Hepato-Biliary-Pancreatic Surgery, Shizuoka Cancer Center, Shizuoka, Japan \\ ${ }^{2}$ Medical Genetics Division, Shizuoka Cancer Center Research Institute, Shizuoka, Japan \\ ${ }^{3}$ Division of Pathology, Shizuoka Cancer Center, Shizuoka, Japan \\ ${ }^{4}$ Cancer Diagnostics Research Division, Shizuoka Cancer Center Research Institute, Shizuoka, Japan \\ ${ }^{5}$ Regional Resources Division, Shizuoka Cancer Center Research Institute, Shizuoka, Japan \\ ${ }^{6}$ Shizuoka Cancer Center Hospital and Research Institute, Shizuoka, Japan \\ Correspondence to: Yukiyasu Okamura, email: yu.okamura@scchr.jp \\ Keywords: hepatocellular carcinoma; integrated gene expression profiling; CYP2C19 gene; down-regulation; recurrence-free \\ survival \\ Received: February 05, 2018 Accepted: April 05, $2018 \quad$ Published: April 24, 2018 \\ Copyright: Ashida et al. This is an open-access article distributed under the terms of the Creative Commons Attribution License \\ 3.0 (CC BY 3.0), which permits unrestricted use, distribution, and reproduction in any medium, provided the original author and \\ source are credited.
}

\section{ABSTRACT}

Project HOPE (High-tech Omics-based Patient Evaluation) began in 2014 using integrated gene expression profiling (GEP) of cancer tissues as well as diathesis of each patient who underwent an operation at our institution. The aim of this study was to clarify the association between the expression of cytochrome P450s (CYP) genes and recurrence of hepatocellular carcinoma (HCC). The present study included 92 patients. Genes with aberrant expression were selected based on a $\geq 10$-fold difference in the expression between tumor and non-tumor tissues. The GEP analysis showed that the down-regulated genes in tumor tissue were CYP3A4 in 56 patients (61\%), CYP2C8 in 44 patients $(48 \%)$, CYP2C19 in 30 patients (33\%), CYP2D6 in 11 patients $(12 \%)$, CYP3A5 in 7 patients ( $8 \%)$ and CYP1B1 in 2 patients $(2 \%)$. There was no patients with down-regulation of the CYP17A1 gene. A multivariate analysis revealed that the presence of microscopic portal invasion (hazard ratio [HR] 2.57, 95\% confidence interval [CI] 1.30-5.05 $P=0.006$ ), the presence of intrahepatic-metastasis (HR 3.09 95\% CI 1.52-6.29P= 0.002) and down-regulation of the CYP2C19 gene (HR $3.6995 \%$ CI 1.83-7.46 $P<0.001$ ) were independent predictors for the recurrence-free survival (RFS). The down-regulation of the CYP2C19 gene were correlated with the RFS in HCC.

\section{INTRODUCTION}

Hepatocellular carcinoma (HCC) is the thirdmost common cause of cancer-related death worldwide, with exceedingly high rates in eastern/south-eastern Asia [1]. HCC usually develops in the setting of chronic inflammation due to viral hepatitis, excess alcohol consumption and metabolic diseases. The mechanism of liver carcinogenesis involves genetic, epigenetic, transcriptomic and metabolic changes that form its unique molecular fingerprint [2]. To reduce the cancer related death of HCC, elucidating the molecular mechanisms and developing novel biomarkers are essential, and many researchers have reported the results of whole-genome sequencing analyses [3-6] and microarray studies [7-11].

Project HOPE (High-tech Omics-based Patient Evaluation) began in 2014 using whole-exome sequencing and integrated gene expression profiling (GEP) of each 
cancer tissue as well as diathesis of each patient, who underwent surgery at Shizuoka Cancer Center Hospital [12]. As part of project HOPE, we previously reported the results of a GEP analysis for $\mathrm{HCC}$, in which we extracted the top ten genes that were frequently up-regulated or down-regulated in tumor tissue from 820 cancer-related genes (SCC-820) [13]. Moreover, when the relationships between the expression of the extracted genes and overall survival and early recurrence were analyzed, cytochrome P450s (CYP) 3A4 was shown to be the only predictor of overall survival and early recurrence. We therefore concluded that CYP3A4 may be a novel biomarker for HCC [13]. Looking closely at the SCC-820 genes that were frequently up-regulated or down-regulated in tumor tissue, especially those that were down-regulated-in addition to CYP3A4 - both CYP2C8 and CYP2C19 were included in the top thirty genes (Supplementary Table 1). We therefore focused on the CYP family in the present study. Although impaired activity and expression of CYP proteins and genes in HCC were reported [14], little is known about the prognostic impact of the CYP gene expression status for HCC [15-18]. The aim of this study was to clarify the association between the oncological behavior of HCC and expression of CYP genes and to identify a novel biomarker for the prognosis of HCC.

\section{RESULTS}

\section{GEP analyses}

Among the CYP family genes, seven genes, (CYP3A4, CYP2C8, CYP2C19, CYP2D6, CYP3A5, CYP1B1 and CYP17A1) were included in the SCC-
820 genes [19]. The genes found to be down-regulated in tumor tissue were CYP3A4 in 56 patients $(61 \%)$, CYP2C8 in 44 patients (48\%), CYP2C19 in 30 patients (33\%), CYP2D6 in 11 patients (12\%), CYP3A5 in 7 patients $(8 \%)$ and CYP1B1 in 2 patients $(2 \%)$. There was no patients with down-regulation of the CYP17A1 gene (Figure 1). We used these six down-regulated genes as candidate novel biomarkers for predicting the recurrencefree survival (RFS) in patients with HCC.

\section{Prognostic factors for the RFS}

In the univariate analysis, des-gamma-carboxy prothrombin $(\mathrm{DCP})<40 \mathrm{mAU} / \mathrm{mL}(P=0.010)$, a maximum tumor diameter $\geq 50 \mathrm{~mm}(P=0.012)$, multiple tumors $(P=0.018)$, the presence of microscopic portal invasion $(P<0.001)$, the presence of microscopic venous invasion $(P=0.007)$, the presence of microsatellite lesions $(P<0.001)$, Union for International Cancer Control (UICC) stage $\geq$ II $(P<0.001)$, down-regulation of the CYP2C8 gene $(P=0.003)$, down-regulation of the CYP2C19 gene $(P<0.001)$, down-regulation of the CYP2D6 gene $(P<0.001)$, down-regulation of the CYP3A5 gene $(P=0.017)$, and down-regulation of the CYP1B1 gene $(P=0.004)$ were significant predictors of the RFS. The multivariate analysis to identify novel biomarkers revealed that the presence of microscopic portal invasion (hazard ratio [HR] 2.57, 95\% confidence interval $[\mathrm{CI}] 1.30-5.05 P=0.006)$, the presence of microsatellite lesions (HR 3.09 95\% CI 1.52-6.29 $P=0.002)$ and down-regulation of the CYP2C19 gene (HR 3.69 95\% CI 1.83-7.46 P<0.001) were independent predictors of the poorer RFS (Table 1). The RFS was
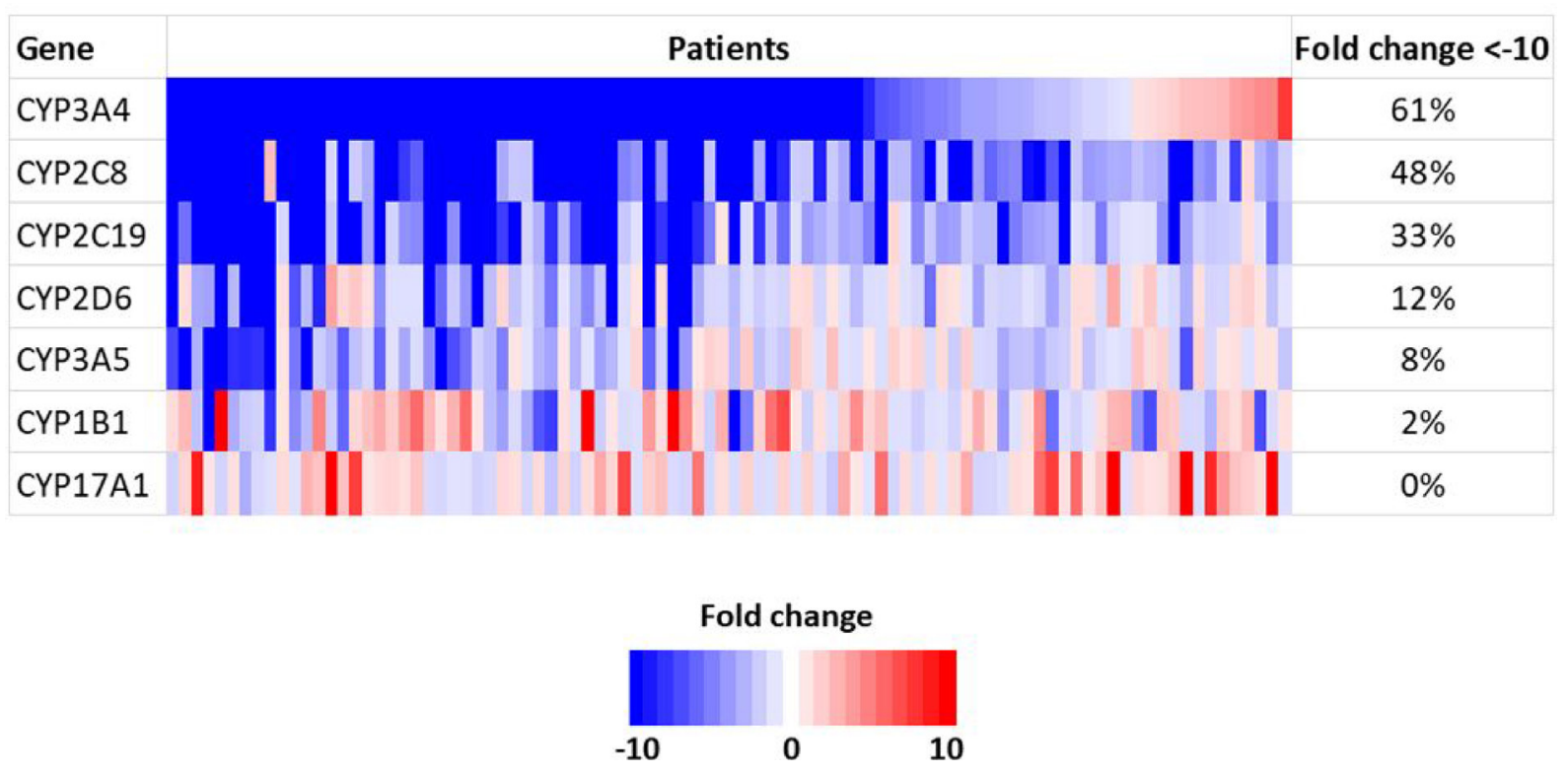

Figure 1: Gene expression of CYP family genes using a microarray analysis. 
Table 1: Prognostic factors for recurrence-free survival by univariate and multivariate analysis

\begin{tabular}{|c|c|c|c|c|c|}
\hline Variables & & & Univariate & Multivariate & \\
\hline & Number & 2-years survival (\%) & $P$ & $\begin{array}{c}\text { Hazard ratio (95\% } \\
\text { Confidence interval) }\end{array}$ & $P$ \\
\hline AFP & & & 0.254 & & \\
\hline$<10 \mathrm{ng} / \mathrm{ml}$ & 44 & 51.4 & & & \\
\hline$\geq 10 \mathrm{ng} / \mathrm{mL}$ & 48 & 63.2 & & & \\
\hline $\mathrm{DCP}$ & & & 0.010 & & 0.180 \\
\hline$<40 \mathrm{mAU} / \mathrm{mL}$ & 15 & 38.9 & & $1.89(0.75-4.78)$ & \\
\hline$\geq 40 \mathrm{mAU} / \mathrm{mL}$ & 77 & 60.8 & & 1 & \\
\hline Histologic differentiation & & & 0.104 & & \\
\hline Well & 17 & 72.1 & & & \\
\hline Others & 75 & 53.4 & & & \\
\hline Size & & & 0.012 & & 0.204 \\
\hline$<50 \mathrm{~mm}$ & 48 & 66.4 & & 1 & \\
\hline$\geq 50 \mathrm{~mm}$ & 44 & 46.0 & & $1.65(0.76-3.54)$ & \\
\hline Tumor number & & & 0.018 & & 0.697 \\
\hline solitary & 72 & 61.3 & & 1 & \\
\hline multiple & 20 & 39.7 & & $1.43(0.60-3.46)$ & \\
\hline Microscopic portal invasion & & & $<0.001$ & & 0.006 \\
\hline absent & 69 & 67.5 & & 1 & \\
\hline present & 23 & 25.3 & & $2.57(1.30-5.05)$ & \\
\hline $\begin{array}{l}\text { Microscopic venous } \\
\text { invasion }\end{array}$ & & & 0.007 & & 0.885 \\
\hline absent & 70 & 64.5 & & 1 & \\
\hline present & 22 & 33.9 & & $1.08(0.40-2.88)$ & \\
\hline Microsatellite lesions & & & $<0.001$ & & 0.002 \\
\hline absent & 74 & 65.4 & & 1 & \\
\hline present & 18 & 22.1 & & $3.09(1.52-6.29)$ & \\
\hline Tumor stage & & & $<0.001$ & & 0.286 \\
\hline I & 46 & 77.2 & & 1 & \\
\hline $\mathrm{II}+\mathrm{III}$ & 46 & 34.4 & & $2.11(0.53-8.33)$ & \\
\hline CYP3A4 gene & & & 0.221 & & \\
\hline Down-regulated & 56 & 58.1 & & & \\
\hline Not down-regulated & 36 & 55.0 & & & \\
\hline CYP2C8 gene & & & 0.003 & & 0.947 \\
\hline Down-regulated & 44 & 43.3 & & $1.03(0.41-2.60)$ & \\
\hline Not down-regulated & 48 & 68.4 & & 1 & \\
\hline CYP2C19 gene & & & $<0.001$ & & $<0.001$ \\
\hline Down-regulated & 30 & 29.4 & & $3.69(1.83-7.46)$ & \\
\hline Not down-regulated & 62 & 69.8 & & 1 & \\
\hline CYP2D6 gene & & & $<0.001$ & & 0.719 \\
\hline Down-regulated & 11 & 12.1 & & $1.28(0.33-4.98)$ & \\
\hline Not down-regulated & 81 & 62.7 & & 1 & \\
\hline CYP3A5 gene & & & 0.017 & & 0.298 \\
\hline
\end{tabular}




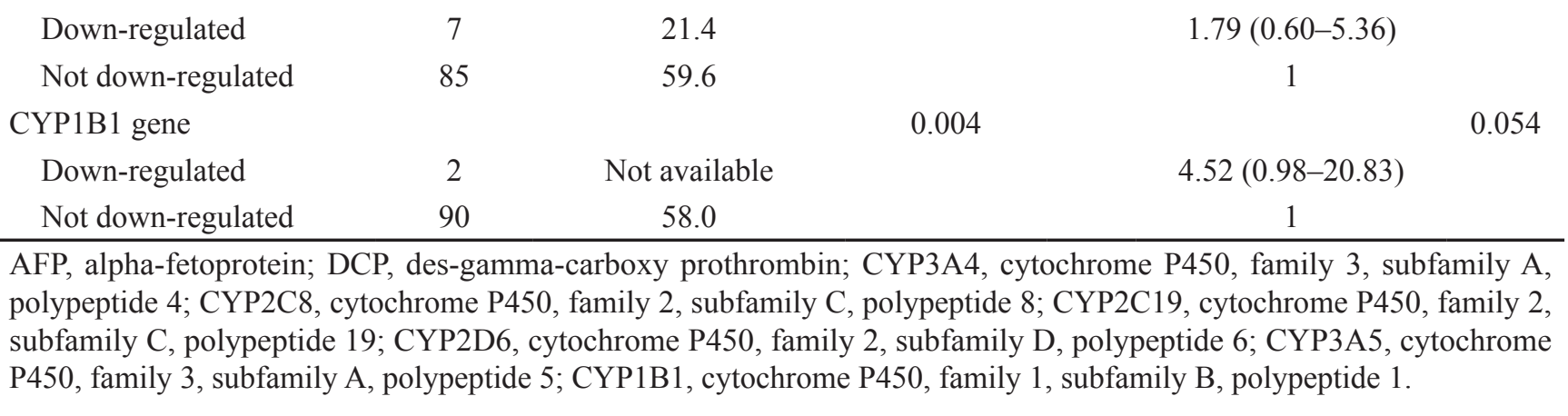

significantly worse in the patients with down-regulation of the $\mathrm{CYP} 2 \mathrm{C} 19$ gene than in those without down-regulation of the CYP2C19 gene (Figure 2A, $P<0.001$ ).

In contrast, the regulation status of the CYP2C19 gene did not affect the overall survival (OS) of our study population (Figure 2B, $P=0.180$ ); however the OS of patients with low CYP2C19 gene expression levels was significantly worse than that of the patients with high CYP2C19 gene expression levels in the extra validation set from the Kaplan-Meier Plotter (KM Plotter) database (Figure 3A, $P<0.001$ ).

\section{A comparison of the clinicopathological factors according to the CYP2C19 gene expression}

The frequency of well-differentiated $\mathrm{HCC}$ in the patients with down-regulation of the CYP2C19 gene was significantly lower than in those without down-regulation of the CYP2C19 gene $(P=0.009)$. The tumor size in the

\section{A. RFS in microarray}

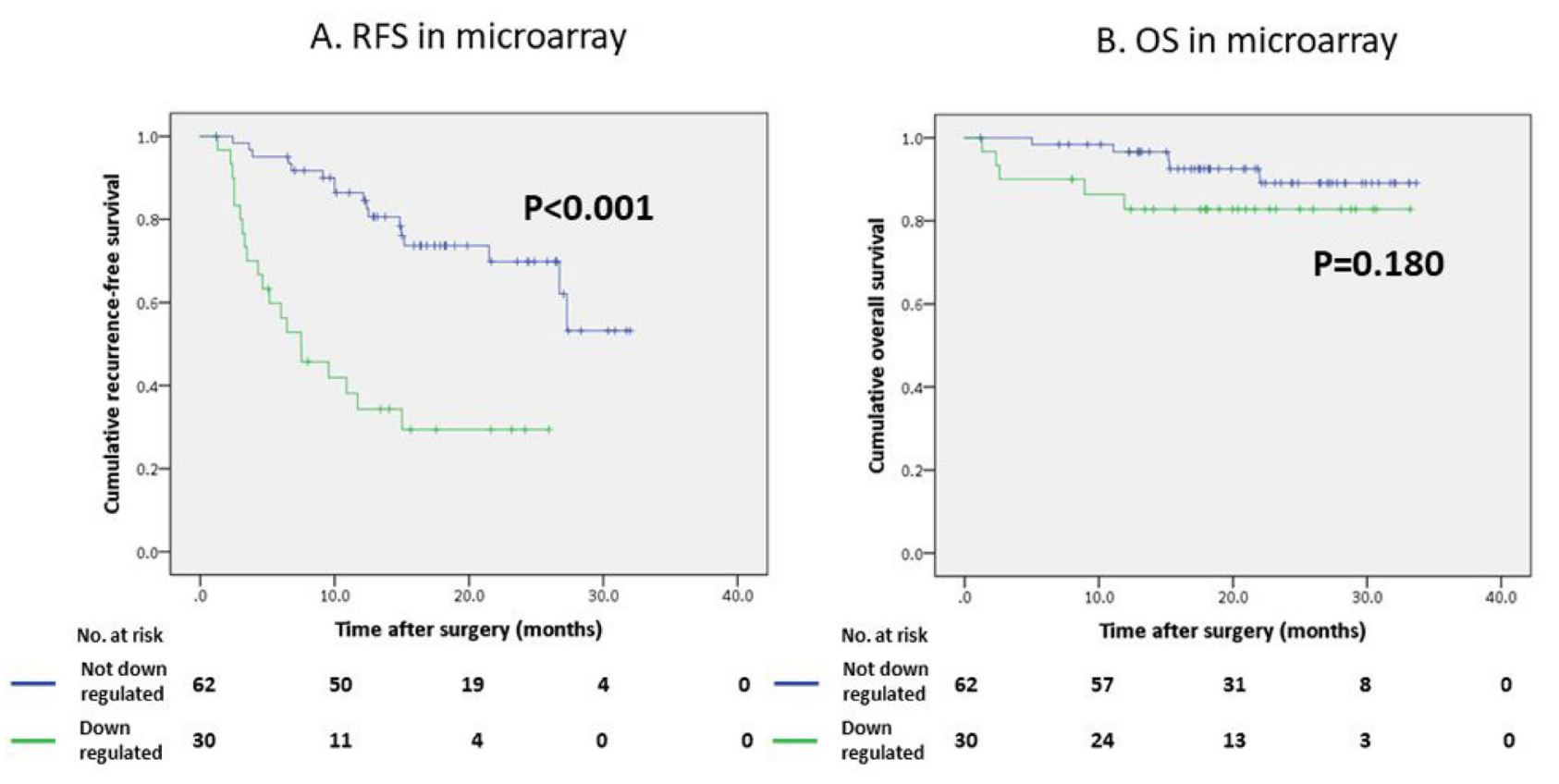

patients with down-regulation of the CYP2C19 gene was significantly greater than in those without down-regulation of the CYP2C19 gene $(P=0.005)$. The frequency of the microscopic portal invasion $(P=0.005)$, microscopic venous invasion $(P=0.012)$ and UICC stage $\geq$ II $(P<0.001)$ in the patients with down-regulation of the CYP2C19 gene were significantly higher than in those without down-regulation of the CYP2C19 gene (Table 2).

\section{Relationship between CYP2C19 gene expression status and recurrence status}

During the study period, recurrence was observed in 20 patients with the down-regulation of the CYP2C19 gene and 17 patients without the down-regulation of the CYP2C19 gene. There were no significant differences between the two groups with regard to the site of recurrence or the number of recurrent sites. The median time to recurrence in the patients with the down-regulation

Figure 2: Survival curves of patients who underwent hepatectomy using the Kaplan-Meier method. (A) Recurrence-free survival (RFS) curve according to the CYP2C19 gene expression in a microarray analysis. (B) Overall survival (OS) curve according to the CYP2C19 gene expression in a microarray analysis. 
of the CYP2C19 gene was significantly shorter than that in patients without the down-regulation of the CYP2C19 gene (4.9 months vs. 12.2 months, respectively; $P=0.002$ ).

\section{Association between the expression of the CYP2C19 gene in a microarray analysis and reverse transcription polymerase chain reaction (RT-PCR) of tumor tissue}

To verify the results of the GEP analysis, we evaluated the association between the expression of the CYP2C19 gene in the microarray analysis and those in RT-PCR of the tumor tissue using Spearman's correlation coefficient. Although the correlation coefficient was relatively low $\left(R^{2}=0.16\right)$, positive correlations were found (Figure 4A, $P<0.001$ )

\section{Association between immunohistochemical staining (IHC) of CYP2C19 protein and RFS}

In the IHC analysis, CYP2C19 protein was stained in the cytoplasm of non-tumor cells (Figure 5A). Figure $5 \mathrm{~B}$ and $5 \mathrm{C}$ show positive and negative staining in the cytoplasm of tumor cells, respectively. The optimum cutoff value of staining for CYP2C19 was 5\% when using the minimum $P$ value approach. The staining for CYP2C19 protein was classified according to the percentage of positive cells: staining in $\geq 5 \%$ of tumor cells was regarded as positive and in $<5 \%$ of cells as negative. Positive staining were observed in tumor cells of 69 patients $(75 \%)$ and negative staining were observed in 23 patients $(25 \%)$. Although the IHC analysis did not reveal a significant correlation between positive staining of CYP2C19 protein

\section{A. OS in the extra-validation set}

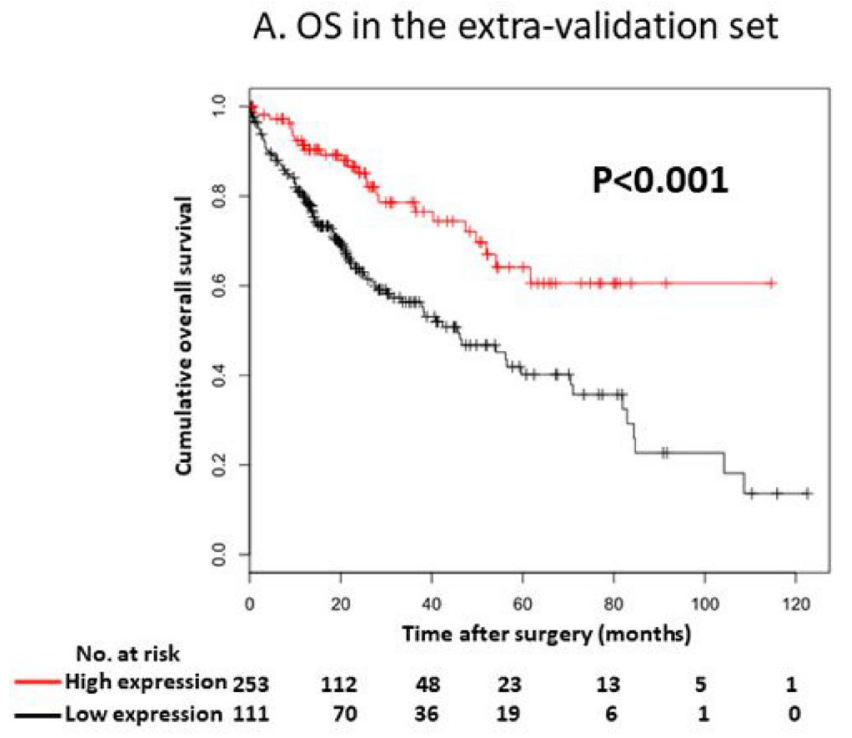

in tumor tissue and the expression of CYP2C19 gene in the microarray analysis (Figure 4B, $P=0.219$ ), the cumulative RFS rate in patients with negative staining of CYP2C19 protein was significantly poorer than in patients with positive staining of CYP2C19 (Figure 3B, $P=0.006$ ).

\section{DISCUSSION}

In the present study, we performed an integrated GEP analysis of CYP genes included in SCC-820 for patients with HCC. We analyzed the relationship between the expression of CYP genes and the prognosis and found that the downregulation of the CYP2C19 gene was an independent predictor of the RFS. Although there were no significant differences in the multivariate analysis, down-regulation of the CYP2C8, CYP2D6, CYP3A5 and CYP1B1 genes was a significant predictor of the RFS in the univariate analysis. Correlations of mRNA expression between several major CYP genes for tumor tissue of HCC have been reported, which may explain our results [14]. To verify the results of the microarray analysis, we performed RT-PCR and IHC. RT-PCR supported the findings of the microarray analysis. In the IHC analysis, the cumulative RFS rate in patients with negative staining of CYP2C19 protein was significantly poorer than in those with positive staining, which was the same result as obtained in the microarray analysis. Therefore, we identified CYP2C19 as a novel, potential clinically useful biomarker for the RFS of HCC. There are no reports of integrated microarray analyses of the GEP for patients with HCC focusing on the expression of CYP genes and their prognostic impact. The present study is the first report to describe the frequency of down-regulation of CYP genes in microarray analyses and its prognostic impact for the RFS.

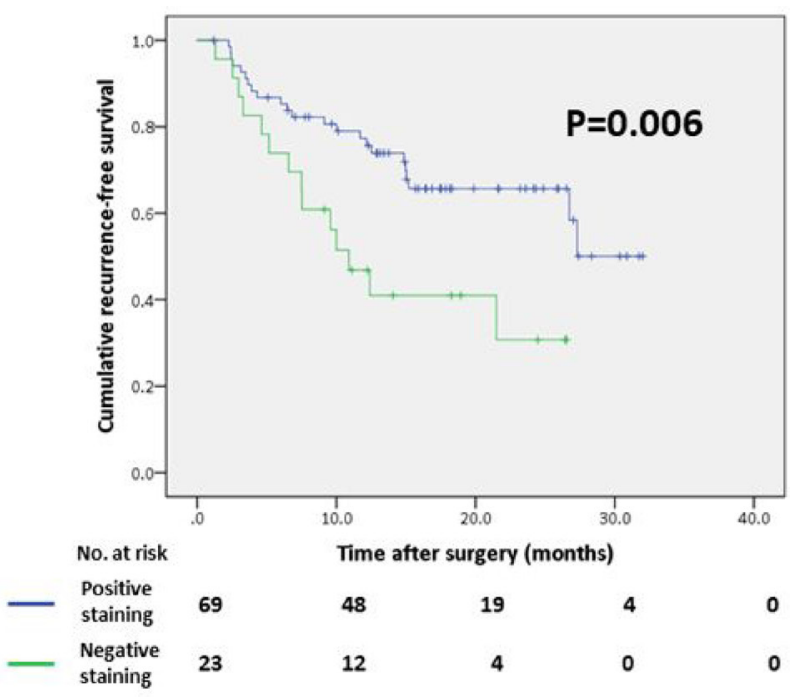

Figure 3: (A) Overall survival (OS) curve according to the CYP2C19 gene expression in the extra-validation set. (B) Recurrence-free survival (RFS) curve according to the IHC status of CYP2C19 protein in our study. 
Table 2: Demographics of patients according to CYP2C19 gene expression

\begin{tabular}{|c|c|c|c|}
\hline & Down regulated $(n=30)$ & Not down regulated $(n=62)$ & $\boldsymbol{P}$ \\
\hline Etiology (viral) & $16(53 \%)$ & $30(48 \%)$ & 0.656 \\
\hline HBsAg (positive) & $7(23 \%)$ & $8(13 \%)$ & 0.204 \\
\hline Anti-HCV Ab (positive) & $9(30 \%)$ & $22(36 \%)$ & 0.602 \\
\hline Cirrhosis (present) & $5(17 \%)$ & $12(19 \%)$ & 0.755 \\
\hline Differentiation (well) & $1(3 \%)$ & $16(26 \%)$ & 0.009 \\
\hline Tumor number (multiple) & $10(33 \%)$ & $10(19 \%)$ & 0.061 \\
\hline Size $(\mathrm{mm})^{\#}$ & $75(10-180)$ & $35(9-160)$ & 0.005 \\
\hline Growth pattern (infiltrative) & $1(3 \%)$ & $4(6 \%)$ & 1.000 \\
\hline Microscopic portal invasion (present) & $13(43 \%)$ & $10(16 \%)$ & 0.005 \\
\hline Microscopic venous invasion (present) & $12(40 \%)$ & $10(16 \%)$ & 0.012 \\
\hline Microsatellite lesions (present) & $8(27 \%)$ & $10(16 \%)$ & 0.232 \\
\hline Tumor stage (II + III) & $23(77 \%)$ & $23(37 \%)$ & $<0.001$ \\
\hline
\end{tabular}

$\mathrm{HBsAg}$, hepatitis B surface antigen; HCV, hepatitis $\mathrm{C}$ virus; $\mathrm{Ab}$, antibody;

CYP2C19, cytochrome P450, family 2, subfamily C, polypeptide 19.

\#The value indicates the median (range).

The present study showed that tumors are more aggressive with regard to differentiation, size, microscopic portal invasion, microscopic venous invasion and stage in patients with down-regulation of the CYP2C19 gene than in those without down-regulation. Several papers have reported that tumor differentiation [20], tumor size [21], microscopic portal invasion [22], microscopic venous invasion [22] and tumor stage [23] are associated with a poor prognosis, and these findings might be related to

\section{A. Correlation between microarray analysis and RT-PCR}

\section{Gene expression in microarray}

(normalized value $\log _{2}$ )

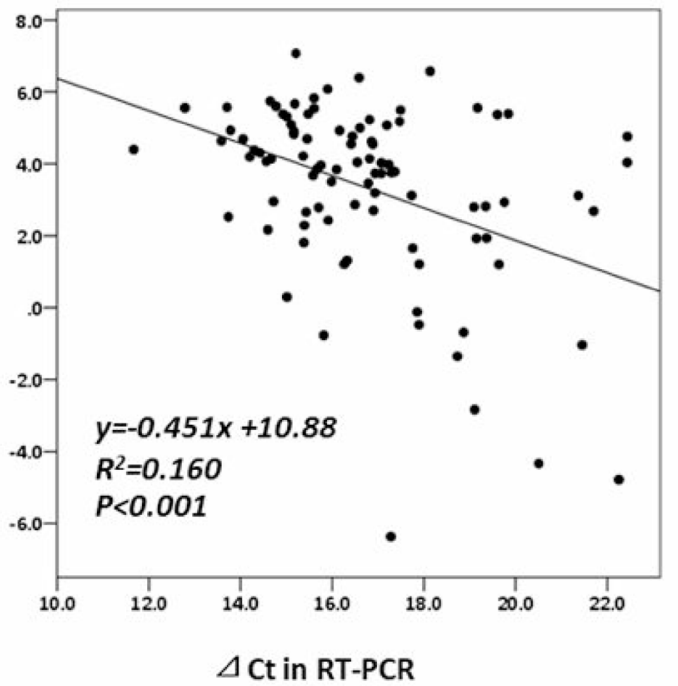

the poor RFS of patients with down-regulation of the CYP2C19 gene compared to those without such downregulation. In addition, the fact that the time to recurrence in the patients with down-regulation of the CYP2C19 gene being significantly shorter than in those without downregulation might be related to the poorer RFS.

CYPs are responsible for about $75 \%$ of drug metabolism and for the metabolism of a huge amount of dietary constituents and endogenous chemicals [24].

\section{B. Correlation between microarray analysis and IHC}

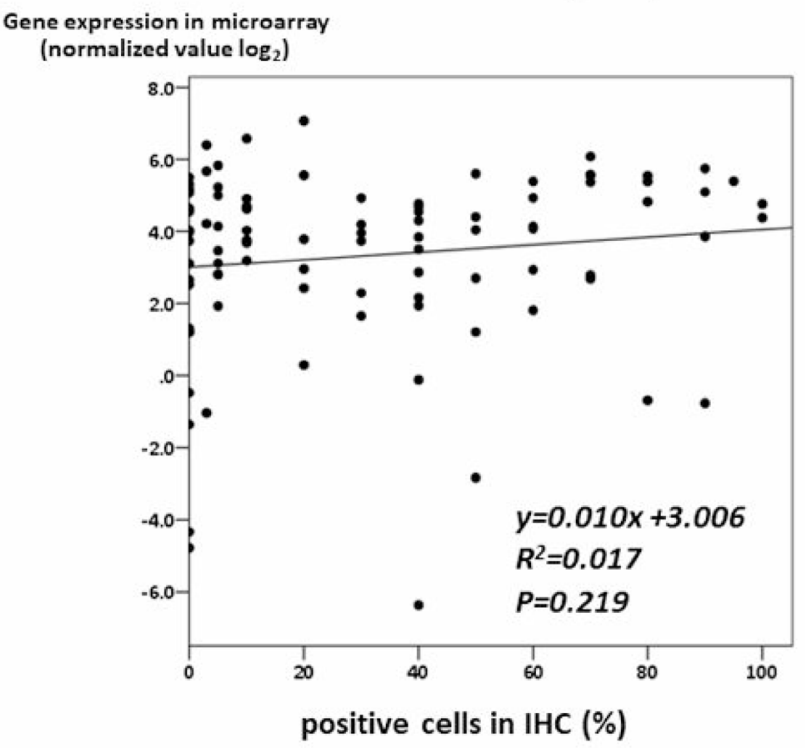

Figure 4: (A) A correlation analysis between the expression of the CYP2C19 gene in a microarray analysis and by RT-PCR of tumor tissue. (B) A correlation analysis between the expression of CYP2C19 gene in a microarray analysis and the IHC staining of CYP2C19 protein of tumor tissue. 
Humans have 59 active CYP genes, and CYP2C19 is mainly expressed in the liver; its enzymes are involved in the metabolism of about $20 \%$ of currently used drugs [25]. Genetic variants of CYP2C19 DNA are polymorphic and the common CYP2C19*2 and CYP2C19*3 alleles have nucleotide mutations that cause a splicing error and generation of a termination codon, which result in enzyme deficiency in non-tumor tissue of the liver [26]. Individuals with such mutations are called poor metabolizers (PMs), and this status is most common among Asians (35\% allele frequency) [27]. Chau et al. reported that PM status of CYP2C19 is associated with an increased incidence of HCC development and suggested that CYP2C19 plays a role in the detoxification of carcinogens [28]. Wang et al. reported a comprehensive meta-analysis that examined the CYP2C19 polymorphisms and the relationship with several cancers, including $\mathrm{HCC}$, and found that PM status of CYP2C19 most likely contributes to cancer susceptibility. They also suggested that CYP2C19 influences the metabolism, particularly detoxification of the carcinogens as a tumor suppressor [29]. The downregulation of CYP2C19 might therefore be associated with a lower metabolism of carcinogens, which leads to higher exposure of carcinogens. As a result, carcinogenesis and proliferation easily occurs in patients with downregulation of the CYP2C19 gene, thereby leading to an aggressive manifestation and a poor prognosis of HCC.

Although the correlation coefficient was relatively low $\left(R^{2}=0.16\right)$, significant correlations between the expression of the CYP2C19 gene in microarray analyses and the expression of the CYP2C19 gene in RT-PCR were found. These suggest that the results of GEP using the microarray were correct. However, microarray analyses and RT-PCR are difficult to perform in daily clinical practice. The present study therefore confirmed the expression of the CYP2C19 protein using IHC, and the cumulative RFS rate in patients with negative staining of CYP2C19 protein was significantly poorer than that in patients with positive CYP2C19 staining, which was similar to the results of the microarray analysis.
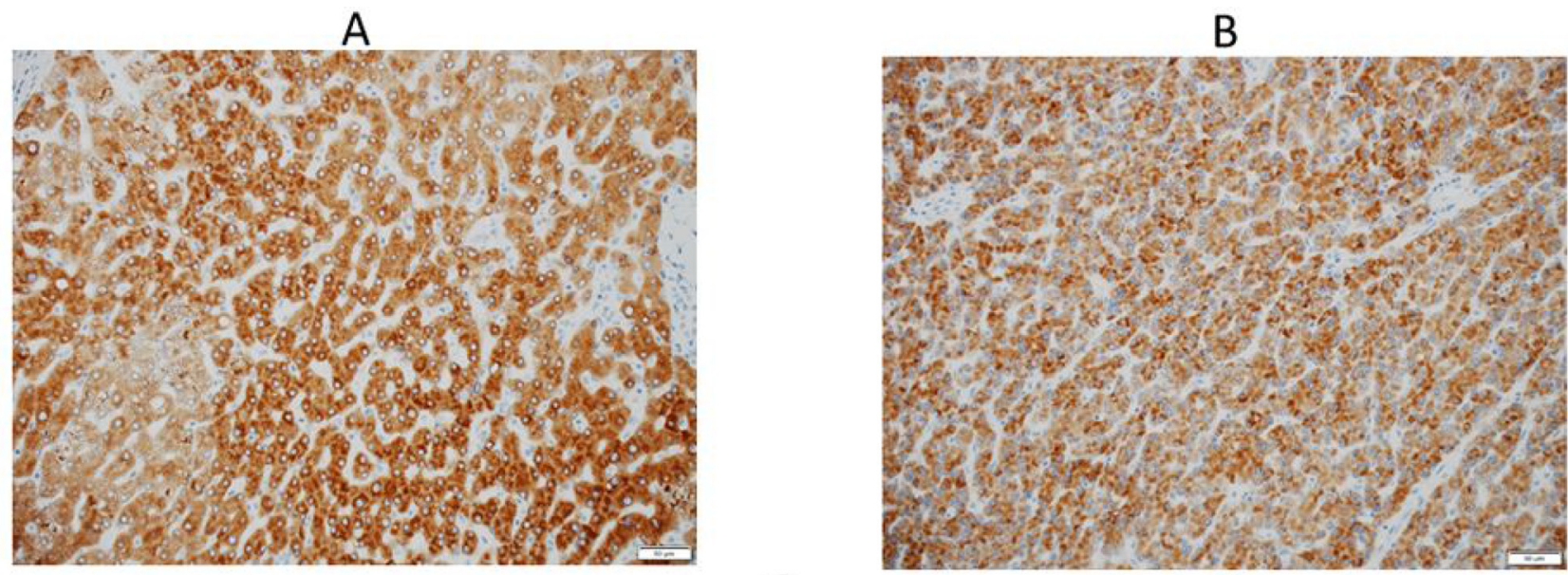

C

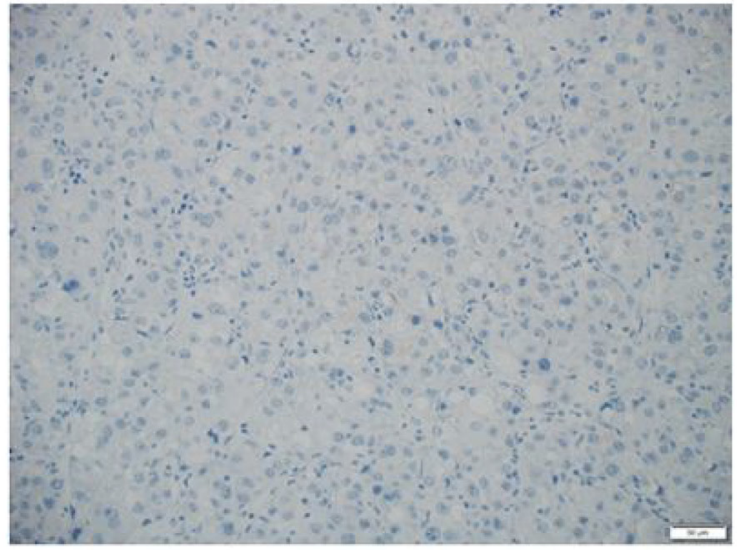

Figure 5: (A) An IHC analysis of CYP2C19 in non-tumor tissue, and cytoplasm of the hepatocyte is positively stained. (B) An IHC analysis of CYP2C19 in tumor tissue, which showed positive staining in the cytoplasm. (C) An IHC analysis of CYP2C19 in tumor tissue, which showed negative staining. 
No significant correlations were found between the CYP2C19 protein staining status in the IHC analysis and the expression of the CYP2C19 gene in the microarray analysis, which might be a weak point of the present study. Zhang et al. reported that the expression of CYP2C subfamily proteins, such as CYP2C19, CYP2C8 and CYP2C9, was partially post-transcriptionally regulated by microRNA-103 and 107 [30]. They reported that there were no correlation between the protein levels of CYP2Cs and the mRNA levels of CYP2Cs in human liver samples. This may be why the expression of the CYP2C19 gene in the microarray analysis and the IHC staining status of the CYP2C19 protein were not significantly correlated. Although these mechanisms should be verified in the future, we have confirmed the utility of CYP2C19 protein as a novel biomarker for predicting the prognosis in daily clinical practice. At the time of writing an appropriate adjuvant chemotherapy regimen for $\mathrm{HCC}$ remains to be established, and a shortened follow-up interval may be beneficial for patients with negative CYP2C19 protein staining as these patients were potentially high risk of recurrence. Moreover, to improve the prognosis of HCC, the proper identification of HCC patients who may benefit from adjuvant chemotherapy will be necessary.

Regarding the mechanisms underlying the downregulation of the CYP2C19 gene in the tumor tissue of HCC, the expression of the CYP2C19 gene was regulated by several nuclear receptors and transcription factors, including the constitutive androstane receptor (CAR), pregnane $\mathrm{X}$ receptor, glucocorticoid receptor, and hepatocyte nuclear factor-3g. Of these, CAR seemed to play a central role and had a strong association with the basal expression of CYP2C19 [31]. Promoter hypermethylation has been reported to result in repression of CAR expression, which induced the down-regulation of the CYP2C19 gene, in human non-cancerous liver and human hepatoma cell lines [32]. In contrast, however, Burns et al. reported that the relationships between already known transcription factors for CYP2C19 and the expression of CYP2C19 gene in human liver samples accounted for less than $70 \%$ of the variability in CYP2C19 mRNA levels. They suggested that an as-yet-un-identified master regulator of CYP2C19 transcription may itself be a target of epigenetic control [33]. Although the precise mechanisms underlying the down-regulation of the CYP2C19 gene were not elucidated in human HCC tissue, several mechanisms, especially epigenetic modification, such as promoter hyper-methylation of CAR might repress the expression of the CYP2C19.

There are several limitations associated with the present study. First, among the numerous active CYP genes, we focused on only the seven major genes included in 820 cancer-related genes. Second, the follow-up period was relatively short and the number of the patients was relatively small in the present study. For these reasons, there was no significant association between OS and the CYP2C19 expression status and to compensate for this limitation, a further analysis was performed using the extra-validation set. Further prospective multi-institutional studies are therefore needed to validate the results of the present study objectively.

In conclusion, the down-regulation of the CYP2C19 gene and protein were found to be correlated with the RFS in $\mathrm{HCC}$.

\section{MATERIALS AND METHODS}

\section{Subjects}

Surgically resected tumor specimens were obtained from 92 consecutive patients who underwent curative resection for HCC at the Division of HepatoBiliary-Pancreatic Surgery of Shizuoka Cancer Center Hospital between January 2014 and October 2016 and had enrolled in Project HOPE. All pathological slides of specimens from those patients were reviewed. Clinical and pathological data were collected from our prospectively recorded database. The patient characteristics have been previously described [13]. Hepatitis B virus (HBV) and hepatitis $\mathrm{C}$ virus (HCV) infection were defined based on the detection of HBsAg and HCVAb, respectively. The tumor stage was also assessed based on the seventh edition of the UICC classification [34]. Ethical approval for all experimental protocols and study was obtained from the institutional review board at the Shizuoka Cancer Center (Authorization Number: 25-33). Written informed consent was obtained from all patients enrolled in the study. All experiments using clinical samples were carried out in accordance with the approved guidelines.

\section{Clinical samples}

Tumor tissue samples with sizes corresponding to weights of $\geq 0.1 \mathrm{~g}$ were dissected from resected specimens, along with samples of surrounding normal tissue. The areas from which tumor samples were dissected were visually assessed as containing $\geq 50 \%$ tumor content. For the RNA analysis, tissue samples were submerged in RNAlater solution (Thermo Fisher Scientific), minced, and stored at $4^{\circ} \mathrm{C}$ before RNA extraction. In cases involving multiple tumors, tissue samples were collected from the largest tumor.

\section{RNA isolation}

Total RNA was extracted from approximately $10 \mathrm{mg}$ of minced tissue samples using the miRNeasy Mini Kit (Qiagen) as described previously [19]. RNA samples with RNA integrity number $\geq 6.0$ were used for the microarray analysis. 


\section{The GEP analysis}

The microarray analysis was performed as described previously [19]. In brief, total RNA (100 ng) was fluorescence-labeled and hybridized to the SurePrint G3 Human Gene Expression $8 \times 60 \mathrm{~K}$ v2 Microarray (Agilent Technologies). The microarray analysis was performed in accordance with the MIAME guidelines [35]. Data analysis was performed using the GeneSpring GX software program (Agilent Technologies) and Microsoft Excel. Raw signal intensity values were log-transformed and normalized to the 75th percentile. The fold-change between the tumor and non-tumor tissues from the same patient was calculated using the normalized intensity values. Genes with expression levels with $\geq 10$-fold in tumor tissues were defined as up-regulated and genes with expression levels with $\leq-10$-fold in tumor tissues were defined as down-regulated [19]. For external data validation, the KM Plotter database, an integrated dataset including 364 patients from three major cancer research centers (Berlin, Bethesda and Melbourne datasets), was accessed at http://kmplot.com/analysis/[36]. This dataset was used to verify the prognostic impact of the CYP2C19 gene expression status on OS.

\section{RT-PCR for the mRNA analysis}

Quantitative mRNA levels were determined using real-time RT-PCR with the Applied Biosystems 7900 HT Sequence Detection System (Applied Biosystems), a TaqMan Gene Expression assay for human CYP2C19 (assay ID Hs00426380; Applied Biosystems), and a Eukaryotic 18S rRNA Endogenous Control (Applied Biosystems) as an endogenous control. cDNA was generated using $100 \mathrm{ng}$ of the total RNA and a Highcapacity cDNA Reverse Transcription Kit (Applied Biosystems). RT-PCR was carried out in a total volume of $20 \mu \mathrm{L}$ using $100 \mathrm{ng}$ of cDNA, TaqMan Fast Advanced Master Mix (Applied Biosystems), and the respective TaqMan reagents for target genes. The conditions for amplification were $95^{\circ} \mathrm{C}$ for $20 \mathrm{~s}$ followed by 40 cycles at $95^{\circ} \mathrm{C}$ for $1 \mathrm{~s}$ and $60^{\circ} \mathrm{C}$ for $20 \mathrm{~s}$. Samples were analyzed in triplicate as biological replicates. The levels of CYP2C19 mRNA were defined from the cycle threshold $(\mathrm{Ct})$. The $\mathrm{Ct}$ was normalized with reference to the level of 18S rRNA in each sample using the comparative $\mathrm{Ct}$ method, and $\Delta \mathrm{Ct}$ was defined as the difference in the $\mathrm{Ct}$ values for CYP2C19 mRNA and 18S rRNA [37].

\section{The IHC analysis}

All of the resected specimens were fixed in 10\% formalin, dehydrated and embedded in paraffin. Paraffin sections of 3- $\mu \mathrm{m}$ thickness containing representative wellpreserved HCC samples were used for the IHC analysis. IHC was performed using the Bond III automated stainer and BOND Polymer Refine Detection kit (Leica
Biosystems). The sections were pretreated with epitope retrieval BOND1 for $20 \mathrm{~min}$ at $100^{\circ} \mathrm{C}$ and then reacted with anti-CYP450 2C19 rabbit polyclonal antibody at 1.200 dilution (HPA015066, Sigma-Aldrich). After reaction with diaminobenzidine chromogen, the sections were counterstained with hematoxylin.

To avoid bias, two independent pathologists evaluated the specimens in a blinded manner as follows. The intensity of the CYP2C19 protein expression in tumor cells was described as the percentage of stained cells. The optimum cut-off CYP2C19 protein staining value for dividing the patients into 2 groups was determined using the minimum $P$ value approach. The optimum cut-off point for dividing the patients based on their recurrence-free survival was also determined using the minimum $P$ value approach, which was performed using a log-rank test $[38,39]$.

\section{Statistical analyses}

The categorical variables were compared using the chisquared test or Fisher's exact test, as appropriate. Continuous variables were compared using the Mann-Whitney $U$ test. The cumulative RFS were analyzed using the KaplanMeier method and compared using the log-rank test. A Cox proportional hazards model was used for the univariate and multivariate analyses, and all factors found to be significant predictors of the RFS $(P<0.10)$ in the univariate analysis were entered into the multivariate analysis. When converting continuous variables to categorical variables, the AFP and DCP levels were defined as the upper limit of normal at our institution. The cutoff value for the tumor size was determined based on the seventh edition of the UICC classification [34]. The multivariate analysis was performed via the logistic regression method using a backward stepwise selection model. All statistical analyses were performed using the SPSS 24.0 software package (SPSS, Inc., Chicago, IL, USA), and $P$ values of $<0.05$ in 2-tailed tests were considered to be significant.

\section{Abbreviations}

HCC: hepatocellular carcinoma; Project HOPE: high-tech omics-based patient evaluation; GEP: gene expression profiling; AFP: alpha-fetoprotein; DCP: des-gamma-carboxy prothrombin; UICC: Union for International Cancer Control; RT-PCR: reverse transcription polymerase chain reaction; $\mathrm{Ct}$ : cycle threshold; IHC: immunohistochemical; RFS: recurrencefree survival; PMs: poor metabolizers; CAR: constitutive androstane receptor.

\section{Author contributions}

K.Y., M.K., K.U. and K.O. developed the concept of the project HOPE. K.U., T.S., Y.O., T.I., Y.Y. and R.A. performed curative resection for HCC. K.O. isolated 
RNA, analyzed the data of microarray. R.A. performed RT-PCR, IHC, acquired the data of microarray, RT-PCR, IHC, analyzed and interpreted the whole data, performed statistical analysis and drafted the manuscript. Y.O. performed study supervision, revision of the manuscript. Y.K. and T.S. assisted for assessment of IHC. All authors reviewed the manuscript.

\section{ACKNOWLEDGMENTS}

The authors thank Koji Muramatsu and Yuko Watanabe their valuable technical assistance.

\section{CONFLICTS OF INTEREST}

The authors declare that there have no conflicts of interest.

\section{FINANCIAL SUPPORT}

There are no grants or other financial support for this study.

\section{REFERENCES}

1. Bertuccio P, Turati F, Carioli G, Rodriguez T, La Vecchia C, Malvezzi M, Negri E. Global Trends and Predictions in Hepatocellular Carcinoma Mortality. J Hepatol. 2017. https://doi.org/10.1016/j.jhep.2017.03.011.

2. Marquardt JU, Andersen JB, Thorgeirsson SS. Functional and genetic deconstruction of the cellular origin in liver cancer. Nat Rev Cancer. 2015; 15:653-67. https://doi. org/10.1038/nrc4017.

3. Totoki Y, Tatsuno K, Covington KR, Ueda H, Creighton CJ, Kato M, Tsuji S, Donehower LA, Slagle BL, Nakamura H, Yamamoto S, Shinbrot E, Hama N, et al. Trans-ancestry mutational landscape of hepatocellular carcinoma genomes. Nat Genet. 2014; 46:1267-73. https://doi.org/10.1038/ ng.3126.

4. Fujimoto A, Furuta M, Totoki Y, Tsunoda T, Kato M, Shiraishi Y, Tanaka H, Taniguchi H, Kawakami Y, Ueno M, Gotoh K, Ariizumi S, Wardell CP, et al. Whole-genome mutational landscape and characterization of noncoding and structural mutations in liver cancer. Nat Genet. 2016; 48:500-9. https://doi.org/10.1038/ng.3547.

5. Schulze K, Nault JC, Villanueva A. Genetic profiling of hepatocellular carcinoma using next-generation sequencing. J Hepatol. 2016; 65:1031-42. https://doi.org/10.1016/j. jhep.2016.05.035.

6. Cao Y, Agarwal R, Dituri F, Lupo L, Trerotoli P, Mancarella S, Winter P, Giannelli G. NGS-based transcriptome profiling reveals biomarkers for companion diagnostics of the TGFbeta receptor blocker galunisertib in HCC. Cell Death Dis. 2017; 8:e2634. https://doi.org/10.1038/cddis.2017.44.
7. Gao B, Ning S, Li J, Liu H, Wei W, Wu F, Tang Y, Feng $\mathrm{Y}$, Li K, Zhang L. Integrated analysis of differentially expressed mRNAs and miRNAs between hepatocellular carcinoma and their matched adjacent normal liver tissues. Oncol Rep. 2015; 34:325-33. https://doi.org/10.3892/ or.2015.3968.

8. Shi KQ, Lin Z, Chen XJ, Song M, Wang YQ, Cai YJ, Yang NB, Zheng MH, Dong JZ, Zhang L, Chen YP. Hepatocellular carcinoma associated microRNA expression signature: integrated bioinformatics analysis, experimental validation and clinical significance. Oncotarget. 2015; 6:25093-108. https://doi.org/10.18632/oncotarget.4437.

9. Villa E, Critelli R, Lei B, Marzocchi G, Camma C, Giannelli G, Pontisso P, Cabibbo G, Enea M, Colopi S, Caporali C, Pollicino T, Milosa F, et al. Neoangiogenesisrelated genes are hallmarks of fast-growing hepatocellular carcinomas and worst survival. Results from a prospective study. Gut. 2016; 65:861-9. https://doi.org/10.1136/ gutjnl-2014-308483.

10. Wang F, Wang R, Li Q, Qu X, Hao Y, Yang J, Zhao H, Wang Q, Li G, Zhang F, Zhang H, Zhou X, Peng X, et al. A transcriptome profile in hepatocellular carcinomas based on integrated analysis of microarray studies. Diagn Pathol. 2017; 12:4. https://doi.org/10.1186/s13000-016-0596-X.

11. Yang H, Zhang X, Cai XY, Wen DY, Ye ZH, Liang L, Zhang L, Wang HL, Chen G, Feng ZB. From big data to diagnosis and prognosis: gene expression signatures in liver hepatocellular carcinoma. PeerJ. 2017; 5:e3089. https://doi. org/10.7717/peerj.3089.

12. Yamaguchi $\mathrm{K}$, Urakami $\mathrm{K}$, Ohshima $\mathrm{K}$, Mochizuki $\mathrm{T}$, Akiyama Y, Uesaka K, Nakajima T, Takahashi M, Tamai $\mathrm{S}$, Kusuhara M. Implementation of individualized medicine for cancer patients by multiomics-based analyses-the Project HOPE. Biomed Res. 2014; 35:407-12. https://doi. org/10.2220/biomedres.35.407.

13. Ashida R, Okamura Y, Ohshima K, Kakuda Y, Uesaka $\mathrm{K}$, Sugiura T, Ito T, Yamamoto Y, Sugino T, Urakami K, Kusuhara M, Yamaguchi K. CYP3A4 Gene Is a Novel Biomarker for Predicting a Poor Prognosis in Hepatocellular Carcinoma. Cancer Genomics Proteomics. 2017; 14:445-53. https://doi.org/10.21873/cgp.20054.

14. Yan T, Lu L, Xie C, Chen J, Peng X, Zhu L, Wang Y, Li Q, Shi J, Zhou F, Hu M, Liu Z. Severely Impaired and Dysregulated Cytochrome P450 Expression and Activities in Hepatocellular Carcinoma: Implications for Personalized Treatment in Patients. Mol Cancer Ther. 2015; 14:2874-86. https://doi.org/10.1158/1535-7163.mct-15-0274.

15. Ho JC, Cheung ST, Leung KL, Ng IO, Fan ST. Decreased expression of cytochrome $\mathrm{P} 450$ 2E1 is associated with poor prognosis of hepatocellular carcinoma. Int J Cancer. 2004; 111:494-500. https://doi.org/10.1002/ijc.20282.

16. Zhang K, Jiang L, He R, Li BL, Jia Z, Huang RH, Mu Y. Prognostic value of CYP2W1 expression in patients with human hepatocellular carcinoma. Tumour Biol. 2014; 35:7669-73. https://doi.org/10.1007/s13277-014-2023-9. 
17. Jiang F, Chen L, Yang YC, Wang XM, Wang RY, Li L, Wen W, Chang YX, Chen CY, Tang J, Liu GM, Huang WT, $\mathrm{Xu}$ L, et al. CYP3A5 Functions as a Tumor Suppressor in Hepatocellular Carcinoma by Regulating mTORC2/ Akt Signaling. Cancer Res. 2015; 75:1470-81. https://doi. org/10.1158/0008-5472.can-14-1589.

18. Wang X, Yu T, Liao X, Yang C, Han C, Zhu G, Huang K, Yu L, Qin W, Su H, Liu X, Peng T. The prognostic value of CYP2C subfamily genes in hepatocellular carcinoma. Cancer Med. 2018. https://doi.org/10.1002/cam4.1299.

19. Ohshima K, Hatakeyama K, Nagashima T, Watanabe Y, Kanto K, Doi Y, Ide T, Shimoda Y, Tanabe T, Ohnami S, Ohnami S, Serizawa M, Maruyama K, et al. Integrated analysis of gene expression and copy number identified potential cancer driver genes with amplification-dependent overexpression in 1,454 solid tumors. Sci Rep. 2017; 7:641. https://doi.org/10.1038/s41598-017-00219-3.

20. Adachi E, Maehara S, Tsujita E, Taguchi K, Aishima S, Rikimaru T, Yamashita Y, Tanaka S. Clinicopathologic risk factors for recurrence after a curative hepatic resection for hepatocellular carcinoma. Surgery. 2002; 131:S148-52.

21. Goh BK, Teo JY, Chan CY, Lee SY, Jeyaraj P, Cheow PC, Chow PK, Ooi LL, Chung AY. Importance of tumor size as a prognostic factor after partial liver resection for solitary hepatocellular carcinoma: Implications on the current AJCC staging system. J Surg Oncol. 2016; 113:89-93. https://doi. org/10.1002/jso.24099.

22. Kluger MD, Salceda JA, Laurent A, Tayar C, Duvoux C, Decaens T, Luciani A, Van Nhieu JT, Azoulay D, Cherqui D. Liver resection for hepatocellular carcinoma in 313 Western patients: tumor biology and underlying liver rather than tumor size drive prognosis. J Hepatol. 2015; 62:1131-40. https://doi.org/10.1016/j.jhep.2014.12.018.

23. Yamamoto Y, Ikoma H, Morimura R, Shoda K, Konishi H, Murayama Y, Komatsu S, Shiozaki A, Kuriu Y, Kubota T, Nakanishi M, Ichikawa D, Fujiwara H, et al. Posthepatectomy survival in advanced hepatocellular carcinoma with portal vein tumor thrombosis. World J Gastroenterol. 2015; 21:246-53. https://doi.org/10.3748/wjg.v21.i1.246.

24. Ingelman-Sundberg M. Human drug metabolising cytochrome P450 enzymes: properties and polymorphisms. Naunyn Schmiedebergs Arch Pharmacol. 2004; 369:89104. https://doi.org/10.1007/s00210-003-0819-z.

25. Rodriguez-Antona $C$, Ingelman-Sundberg M. Cytochrome P450 pharmacogenetics and cancer. Oncogene. 2006; 25:1679-91. https://doi.org/10.1038/sj.onc.1209377.

26. Mochizuki J, Murakami S, Sanjo A, Takagi I, Akizuki S, Ohnishi A. Genetic polymorphisms of cytochrome P450 in patients with hepatitis $\mathrm{C}$ virus-associated hepatocellular carcinoma. J Gastroenterol Hepatol. 2005; 20:1191-7. https://doi.org/10.1111/j.1440-1746.2005.03808.x.

27. Desta Z, Zhao X, Shin JG, Flockhart DA. Clinical significance of the cytochrome P450 2C19 genetic polymorphism. Clin Pharmacokinet. 2002; 41:913-58. https://doi.org/10.2165/00003088-200241120-00002.
28. Chau TK, Marakami S, Kawai B, Nasu K, Kubota T, Ohnishi A. Genotype analysis of the CYP2C19 gene in HCV-seropositive patients with cirrhosis and hepatocellular carcinoma. Life Sci. 2000; 67:1719-24.

29. Wang H, Song K, Chen Z, Yu Y. Poor metabolizers at the cytochrome $\mathrm{P} 4502 \mathrm{C} 19$ loci is at increased risk of developing cancer in Asian populations. PLoS One. 2013; 8:e73126. https://doi.org/10.1371/journal.pone.0073126.

30. Zhang SY, Surapureddi S, Coulter S, Ferguson SS, Goldstein JA. Human CYP2C8 is post-transcriptionally regulated by microRNAs 103 and 107 in human liver. Mol Pharmacol. 2012; 82:529-40. https://doi.org/10.1124/mol.112.078386.

31. Wortham M, Czerwinski M, He L, Parkinson A, Wan YJ. Expression of constitutive androstane receptor, hepatic nuclear factor 4 alpha, and P450 oxidoreductase genes determines interindividual variability in basal expression and activity of a broad scope of xenobiotic metabolism genes in the human liver. Drug Metab Dispos. 2007; 35:1700-10. https://doi.org/10.1124/dmd.107.016436.

32. Tang X, Ge L, Chen Z, Kong S, Liu W, Xu Y, Zeng S, Chen S. Methylation of the Constitutive Androstane Receptor Is Involved in the Suppression of CYP2C19 in Hepatitis B Virus-Associated Hepatocellular Carcinoma. Drug Metab Dispos. 2016; 44:1643-52. https://doi.org/10.1124/ dmd.116.070243.

33. Burns KE, Shepherd P, Finlay G, Tingle MD, Helsby NA. Indirect regulation of CYP2C19 gene expression via DNA methylation. Xenobiotica. 2017:1-12. https://doi.org/10.10 80/00498254.2017.1372648.

34. Sobin L, Gospodarowicz M, Wittekind C. TNM Classification of Malignant Tumours, 7th ed. (New York: Wiley-Liss). 2009.

35. Brazma A, Hingamp P, Quackenbush J, Sherlock G, Spellman P, Stoeckert C, Aach J, Ansorge W, Ball CA, Causton HC, Gaasterland T, Glenisson P, Holstege FC, et al. Minimum information about a microarray experiment (MIAME)-toward standards for microarray data. Nat Genet. 2001; 29:365-71. https://doi.org/10.1038/ng1201-365.

36. Szasz AM, Lanczky A, Nagy A, Forster S, Hark K, Green JE, Boussioutas A, Busuttil R, Szabo A, Gyorffy B. Crossvalidation of survival associated biomarkers in gastric cancer using transcriptomic data of 1,065 patients. Oncotarget. 2016; 7:49322-33. https://doi.org/10.18632/oncotarget.10337.

37. Livak KJ, Schmittgen TD. Analysis of relative gene expression data using real-time quantitative PCR and the 2(-Delta Delta C(T)) Method. Methods. 2001; 25:402-8. https://doi.org/10.1006/meth.2001.1262.

38. Galon J, Costes A, Sanchez-Cabo F, Kirilovsky A, Mlecnik B, Lagorce-Pages C, Tosolini M, Camus M, Berger A, Wind P, Zinzindohoue F, Bruneval P, Cugnenc PH, et al. Type, density, and location of immune cells within human colorectal tumors predict clinical outcome. Science. 2006; 313:1960-4. https://doi.org/10.1126/science.1129139.

39. Altman DG, Lausen B, Sauerbrei W, Schumacher M. Dangers of using "optimal" cutpoints in the evaluation of prognostic factors. J Natl Cancer Inst. 1994; 86:829-35. 